\title{
Andersen's Syndrome: A Distinct Periodic Paralysis
}

\author{
V. Sansone, MD, ${ }^{*}$ R. C. Griggs, MD,† G. Meola, MD, * L. J. Ptáček, MD, \$ R. Barohn, MD, $\$$ \\ S. Iannaccone, MD," W. Bryan, MD, $\$$ N. Baker, MD, S. J. Janas, MD, W. Scott, MD, \\ D. Ririe, BA, $\ddagger$ and R. Tawil, MD $\dagger$
}

\begin{abstract}
A previous study of 4 patients defined Andersen's syndrome (AS) as a triad of potassium-sensitive periodic paralysis, ventricular dysrhythmias, and dysmorphic features. AS appears to be distinct in terms of its genetic defect from the $\alpha$-subunit of skeletal muscle sodium channel and the cardiac potassium channel responsible for most long QT syndromes (LQT1). We studied 11 additional patients with AS from 5 kindreds. Spontaneous attacks of paralysis were associated with hypokalemia, normokalemia, or hyperkalemia. All 11 patients had similar dysmorphic features. The QT interval was prolonged in all patients although only 4 were symptomatic. Genetic linkage studies excluded linkage to the $\alpha$-subunit of the skeletal muscle sodium channel and to four distinct LQT loci. In addition, none of the common dihydropyridine receptor mutations responsible for hypokalemic periodic paralysis were present. We conclude that (1) AS is a genetically unique channelopathy affecting both cardiac and skeletal membrane excitability, (2) attacks of paralysis may be either hypokalemic or hyperkalemic, (3) a prolonged QT interval is an integral feature of this syndrome, and (4) a prolonged QT interval may be the only sign in an individual from an otherwise typical AS kindred. This may be confused with more common, potentially lethal LQT syndromes.
\end{abstract}

Sansone V, Griggs RC, Meola G, Ptáček LJ, Barohn R, Iannaccone S, Bryan W, Baker N, Janas SJ, Scott W, Riric D, Tawil R. Andersen's syndrome: a distinct periodic paralysis. Ann Neurol 1997;42:305-312

Klein and co-workers [1] were the first to emphasize that in some forms of periodic paralysis $[2,3]$, cardiac dysrhythmias are a primary manifestation of the disease, independent of serum potassium levels (Table 1) $[1,4-12]$. Of the reported cases of periodic paralysis with cardiac involvement, a distinct syndrome has emerged consisting of a triad of episodic weakness, ventricular arrhythmias, and distinctive facial features [4, 10, 13]. First described by Andersen, we named this condition Andersen's syndrome (AS) in a report of 4 patients [13].

In three previously reported kindreds, periodic paralysis was associated with hyperkalemia, but genetic linkage to the skeletal muscle sodium channel was excluded [14-16]. Because $\mathrm{QT}_{c}$ intervals were prolonged in three of four of the reported cases, we screened for and excluded linkage to the long QT syndrome locus on chromosome 11 (LQT1) [17, 18].

We report on 11 additional patients with Andersen's syndrome, describing the distinctive physical features, associated cardiac abnormalities, and the relationship of serum potassium level to the episodic paralysis. In ad- dition, we performed linkage studies to the sodium channel gene [14-16] (hyperkalemic periodic paralysis; HyperKPP) and four LQT loci $[17,18]$. Mutational analysis was performed on the dihydropyridine receptor gene [19] (hypokalemic periodic paralysis, Hypo$\mathrm{KPP})$.

\section{Patients and Methods}

We studied 11 patients from 5 kindreds by neurological examination and electrocardiography (ECG). The index cases had the following: (1) an electromyography (EMG), to assess myotonia according to previously described protocols, including the exercise test [20]; (2) a muscle biopsy; (3) hypokalemic and hyperkalemic challenges according to standard protocols [2]; and (4) 24-hour Holter monitoring. The diagnosis of LQT syndrome was made according to standard criteria $[21,22]$.

For genetic studies [13] in 2 three-generation kindreds we used markers tightly linked to the HyperKPP gene [14-16] and four LQT syndrome loci (LQT1-4) [17, 18, 21]. Kindreds were not large enough to perform linkage analysis to the calcium channel gene, but mutational analysis was performed for possible mutations as previously described [19].
From the * Department of Neurology, University of Milan, S Donato Hospital, Milan, Italy; †Department of Neurology, University of Rochester, Strong Memorial Hospiral, Rochester, NY; $\ddagger$ Department of Human Molecular Genetics, University of Utah, Salt Lake City, UT: $\$$ Department of Neurology, Southwestern Medical Center, and "Pediatric Neurology, Scottish Rite Hospital, Dallas, TX; and Pediatric Neurology, Oregon Health Science University, Portland, $O R$.
Received Jan 31, 1997, and in revised form Mar 7. Accepted for publication Mar 10, 1997.

Address correspondence to Dr Sansone, Department of Neurology, University of Milan, San Donato Hospital, V Morandi 30, 20097 San Donato Milanese, Milan, Italy. 


\begin{tabular}{|c|c|c|c|}
\hline Study & Periodic Paralysis & Cardiac Arrhythmias & Dysmorphisms \\
\hline $\begin{array}{l}\text { Klein et al }[1] \\
\quad(1963 ; \text { sporadic and autosomal dominant })\end{array}$ & $\begin{array}{l}\text { Spont }\left[\mathrm{K}^{+}\right]: 3.7 \\
\mathrm{~K}^{+} \text {challenge: normal } \\
\text { glc challenge: not done } \\
\text { Interattack NE: normal }\end{array}$ & $\begin{array}{l}\text { Supraventricular and ventricular } \\
\text { tachycardias }\end{array}$ & Not mentioned \\
\hline $\begin{array}{l}\text { Lisak et al [4] } \\
\text { (1970; autosomal dominant) }\end{array}$ & $\begin{array}{l}\text { Spont }\left[\mathrm{K}^{+}\right]: 4.5 \\
\mathrm{~K}^{+} \text {challenge: weakness } \\
\text { glc challenge: normal } \\
\text { Interattack myopathy }\end{array}$ & Ventricular tachycardia & Not mentioned \\
\hline $\begin{array}{l}\text { Andersen et al [5] } \\
\text { (1971; sporadic) }\end{array}$ & $\begin{array}{l}\text { Spont }\left[\mathrm{K}^{+}\right]: 4.7 \\
\mathrm{~K}^{+} \text {challenge; not done } \\
\text { glc challenge: weakness } \\
\text { Interattack NE: } \downarrow \text { DTR }\end{array}$ & Ventricular tachycardia & Present \\
\hline $\begin{array}{l}\text { Levitt et al }[6] \\
\quad(1972 ; \text { sporadic })\end{array}$ & $\begin{array}{l}\text { Spont }\left[\mathrm{K}^{+}\right]: 2.8 \\
\mathrm{~K}^{+} \text {challenge: not done } \\
\text { glc challenge: weakness } \\
\text { Interattack NE: } \downarrow \text { DTR }\end{array}$ & Ventricular tachycardia & Not mentioned \\
\hline $\begin{array}{l}\text { Stubbs [7] } \\
\text { (1976; autosomal dominant) }\end{array}$ & $\begin{array}{l}\text { Spont }\left[\mathrm{K}^{+}\right]: 3.1 \\
\mathrm{~K}^{+} \text {challenge: not done } \\
\text { glc challenge: not done } \\
\text { Interattack NE: normal }\end{array}$ & $\begin{array}{l}\text { Bidirectional ventricular } \\
\text { tachycardia }\end{array}$ & Not mentioned \\
\hline $\begin{array}{l}\text { Kramer et al [8] } \\
\text { (1979); aurosomal dominant) }\end{array}$ & $\begin{array}{l}\text { Spont }\left[\mathrm{K}^{+}\right]: 1.5 \\
\mathrm{~K}^{+} \text {challenge: not done } \\
\text { glc challenge: not done } \\
\text { Interattack NE: normal }\end{array}$ & Sinus arrhythmia ${ }^{a}$ & Not mentioned \\
\hline $\begin{array}{l}\text { Yoshimura et al [9] } \\
\text { (1983; sporadic) }\end{array}$ & $\begin{array}{l}\text { Spont }\left[\mathrm{K}^{+}\right]: 4.4 \\
\mathrm{~K}^{+} \text {challenge: weakness } \\
\text { glc challenge: normal } \\
\text { Interattack } \mathrm{NE} \text { : myopathy }\end{array}$ & Ventricular tachycardia & Not mentioned \\
\hline $\begin{array}{l}\text { Gould et al }[10] \\
\text { (1985; autosomal dominant) }\end{array}$ & $\begin{array}{l}\text { Spont }\left[\mathrm{K}^{+}\right] \text {: not done } \\
\mathrm{K}^{+} \text {challenge: weakness } \\
\text { glc challenge: normal } \\
\text { Interattack } \mathrm{NE} \text { : normal }\end{array}$ & $\begin{array}{l}\text { Bidirectional ventricular } \\
\text { tachycardia }\end{array}$ & Present \\
\hline $\begin{array}{l}\text { Fukuda et al [11] } \\
\text { (1988; autosomal dominant) }\end{array}$ & $\begin{array}{l}\text { Spont }\left[\mathrm{K}^{+}\right] \text {: not done } \\
\mathrm{K}^{+} \text {challenge: not done } \\
\text { glc challenge: not done } \\
\text { Interattack NE: normal }\end{array}$ & $\begin{array}{l}\text { Bidirectional ventricular } \\
\text { tachycardia }\end{array}$ & Not mentioned \\
\hline $\begin{array}{l}\text { Baquero et al [12] } \\
\text { (1995; sporadic) }\end{array}$ & $\begin{array}{l}\text { Spont }\left[\mathrm{K}^{+}\right] \text {: not done } \\
\mathrm{K}^{+} \text {challenge: weakness } \\
\text { glc challenge: not done } \\
\text { Interattack } \mathrm{NE} \text { : myopathy }\end{array}$ & $\begin{array}{l}\text { Bidirectional ventricular } \\
\text { tachycardia }\end{array}$ & Not mentioned \\
\hline
\end{tabular}

${ }^{2}$ In this patient, a cardiomyopathy was also found.

Spont $\left[\mathrm{K}^{+}\right]=$serum potassium levels (in $\mathrm{mEq} / \mathrm{L}$ ) during a spontaneous attack of weakness; glc = glucose and insulin challenge; $\mathrm{NE}=$ neurologic examination.

Modified from Rowland LP. Andersen's syndrome? Or Klein-Lisak-Andersen syndrome? Ann Neurol 1994;35:252-253 (Letter).

\section{Case Reports}

PATIENT 1 (FAMILY 1, III-1). A 15-year-old girl was referred for evaluation of recurrent episodic weakness and progressive proximal limb weakness. At 4 years of age, she had a nonfatal cardiac arrest. Bidirectional ventricular tachycardia was diagnosed and she was treated with $\beta$-blockers. At age 10 , she first noted limb weakness on waking, which resolved within 2 hours. Examination revealed short stature $(<3$ rd percentile for age), low-set ears, broad nose, clinodactyly of the fifth fingers, syndactyly of the second and third toes, scoliosis, and hypotrophy of the anterior and posterior compartments of the right leg. Mild psychomotor delay was evident. Shoulder and pelvic girdle weakness (grade 4, Medical Research Coun- cil [MRC]) and atrophy were seen, with Gowers' sign, bilateral scapular winging, compensatory hyperlordosis, and genu recurvatum. There was no clinical myotonia, including lingual myotonia. Tendon reflexes were increased and plantar responses were upgoing. Sensation was normal. Brain and spinal cord magnetic resonance imaging were unremarkable. ECG showed a long QT interval $\left(\mathrm{QT}_{\mathrm{c}}=0.47 \mathrm{msec}\right)$. An oral glucose challenge test $(1.5 \mathrm{~g} / \mathrm{kg})$ resulted in weakness at $\mathrm{K}^{+}$levels of $2.7 \mathrm{mEq} / \mathrm{L}$. Potassium levels during spontaneous attacks of weakness ranged from 2.5 to $3.0 \mathrm{mEq} / \mathrm{L}$. Potassium challenge was not performed because of the risk of precipitating fatal ventricular tachycardias. EMG of limb muscles showed no evidence of myotonia even after cooling. 
Muscle biopsy was consistent with a mild chronic myopathy with tubular aggregates.

PATIENT 2 (FAMILY 1, III-2). The 8-year-old sister of Patient 1 never experienced episodic weakness, although she had occasional bouts of palpitation. Examination showed a slender girl of short stature ( $<3$ rd percentile), mandibular hypoplasia, low-set ears, hypertelorism, clinodactyly of the fifth fingers of both hands, syndactyly of the second and third toes of her left foot (Fig D-F). Findings of neurologic examination were normal. ECG showed a long QT interval $\left(\mathrm{QT}_{\mathrm{c}}=0.48 \mathrm{msec}\right)$.

PATIENT 3 (FAMILY 1, II-2). A 45-year-old man, the father of Patients 1 and 2, had one syncopal episode at age 13. His ECG showed a prolonged QT interval $\left(\mathrm{QT}_{\mathrm{c}}=0.47 \mathrm{msec}\right)$, with runs of ventricular tachycardia. His only episode of muscular weakness occurred at age 18 years after prolonged exercise in military service. The episode resolved spontaneously within 3 hours. Examination showed short stature, broad neck, broad nose, prognathism, clinodactyly of the second fingers of both hands, simple syndactyly of the second and third toes of his feet. Neurologic examination was normal except for decreased tendon reflexes. An oral glucose challenge $(1.5 \mathrm{~g} / \mathrm{kg})$ induced weakness at a potassium level of $3.1 \mathrm{mEq} / \mathrm{L}$ (baseline, $4.5 \mathrm{mEq} / \mathrm{L}$ ). There was no electrical myotonia on EMG and a muscle biopsy specimen showed a mild chronic myopathy with tubular aggregates.

PATIENT 4 (FAMILY 1, I-2). An 87-year-old woman, the paternal grandmother of Patients 1 and 2, had no episodes of weakness. Examination revealed fearures similar to those in other affected family members, ie, low-set ears, mandibular hypoplasia, clinodactyly of the fifth fingers of both hands, and syndactyly between the second and third fingers of both feet. Neuromuscular examination was normal. ECG showed asymptomatic bidirectional ventricular tachycardia and a prolonged $\mathrm{QT}$ interval $\left(\mathrm{QT}_{\mathrm{c}}=0.48 \mathrm{msec}\right)$.

PATIENT 5. A 16-year-old boy was referred for evaluation of episodic weakness. At age 7 , a routine ECG showed asymptomatic ventricular tachycardia. He was treated with amiodarone, which was disconcinued 10 months later when he developed profound symptomatic bradycardia and other amiodarone side effects. A pacemaker was inserted and he was given flecainide. He had no cardiac symptoms thereafter. At age 14 , he had episodes of transient weakness about once every 5 weeks. During one attack, the serum potassium level was $2.7 \mathrm{mEq} / \mathrm{L}$. The family history was negative for any cardiac or neurologic disorder. On examination, his height was normal for age. The following nondisfiguring distinctive features were evident: low-set ears, hypertelorism, micrognathia, bilaterally short index fingers that only come to the distal interphalangeal joint of his middle finger, mild clinodactyly of his fifth fingers, and hypoplastic and low-set thumbs with very smooth and flat palmar creases (Fig. G-I). Neurologic examination showed lid lag but no facial weakness and no grip or percussion myotonia, including lingual myotonia. There was mild wasting of pectoral and hand muscles. Bilat- eral scapular winging was seen with grade $4 \mathrm{MRC}$ shoulder and pelvic girdle weakness. Grade $4 \mathrm{MRC}$ weakness was noted in the hands. Tendon reflexes were normal. The ECG showed a combination of intrinsic and pacemaker-induced rhythms. The QT interval, off flecainide, was prolonged $\left(\mathrm{QT}_{\mathrm{c}}=0.48 \mathrm{msec}\right)$. Oral potassium $(0.05 \mathrm{~g} / \mathrm{kg})$ did not induce weakness $(5.1 \mathrm{mEq} / \mathrm{L}$ at 60 minutes). The serum potassium level during a spontaneous attack was $2.7 \mathrm{mEq} / \mathrm{L}$. EMG and muscle biopsy were normal. Both parents were asymptomatic with normal ECGs.

PATIENT 6 (FAMILY 2, II-1). A 14-year-old girl had a 10 year history of episodic weakness occurring at rest after heavy exercise. The attacks lasted 3 to 5 days and were ameliorated by continued physical activity. Serum potassium levels were consistently normal during attacks. ECG showed ventricular dysrhythmias leading to diagnosis of LQT syndrome $\left(\mathrm{QT}_{c}\right.$ $=0.47 \mathrm{msec}$ ) and she was given $\beta$-blockers. Asymptomatic ventricular tachyarrhythmias persisted and she was given verapamil, which was associated with worsening of limb muscles that improved when the drug was discontinued. Examination revealed a slender girl, short and thin for age (25th percentile) with micrognathia, low-set ears, hypertelorism, and mild clinodactyly with long palms bilaterally. Neurologic examination showed mild facial weakness, grade $4 \mathrm{MRC}$ shoulder and pelvic girdle weakness, and normal tendon reflexes. An oral potassium challenge $(0.05 \mathrm{~g} / \mathrm{kg})$ failed to produce weakness, but there was a suboptimal increase in serum $\mathrm{K}^{+}$and she refused further tests. The serum potassium level during a spontaneous attack was $4.3 \mathrm{mEq} / \mathrm{L}$. Needle EMG showed no myotonia; muscle biopsy showed tubular aggregates.

PATIENT 7 (FAMILY 2, 1-1). A 39-year-old woman, the mother of Patient 6, had an isolated asymptomatic prolonged QT interval ( $\mathrm{QT}_{c}=0.48 \mathrm{msec}$ ). She had no episodes of weakness, and baseline potassium levels were normal. No distinctive features were found on examination.

PATIENT 8 (FAMILY 3, IV-1). This boy began having episodes of weakness at age 2 , without apparent precipitating events. Cardiac dysrhythmia was noted on a routine pediatric examination at age 9, with isolated premature ventricular contractions and intermittent short runs of bidirectional ventricular tachycardia. Although asympromatic, he was given flecainide, which prolonged the $\mathrm{QT}_{c}$ interval $\left(\mathrm{QT}_{c}=0.46\right.$ $\mathrm{msec}$ ). On examination, at age 13 , he showed low-set ears, hypertelorism, micrognathia, and clinodactyly of the fifth fingers of both his hands. There was grade $4 \mathrm{MRC}$ proximal limb weakness. Tendon reflexes were reduced. Sensation was normal. Serum potassium values were normal to high between and during spontaneous attacks of weakness (3.7-5.5 $\mathrm{mEq} / \mathrm{L})$. There was no myotonia on EMG, and muscle biopsy showed tubular aggregates.

PATIENT 9 (FAMILY 3, III-1). A 35-year-old woman, the mother of Patient 8 , had asymptomatic ventricular dysrhythmias, with ECG evidence of a prolonged QT interval (QT $=0.52 \mathrm{msec}$ ). She never had episodes of muscle weakness. 

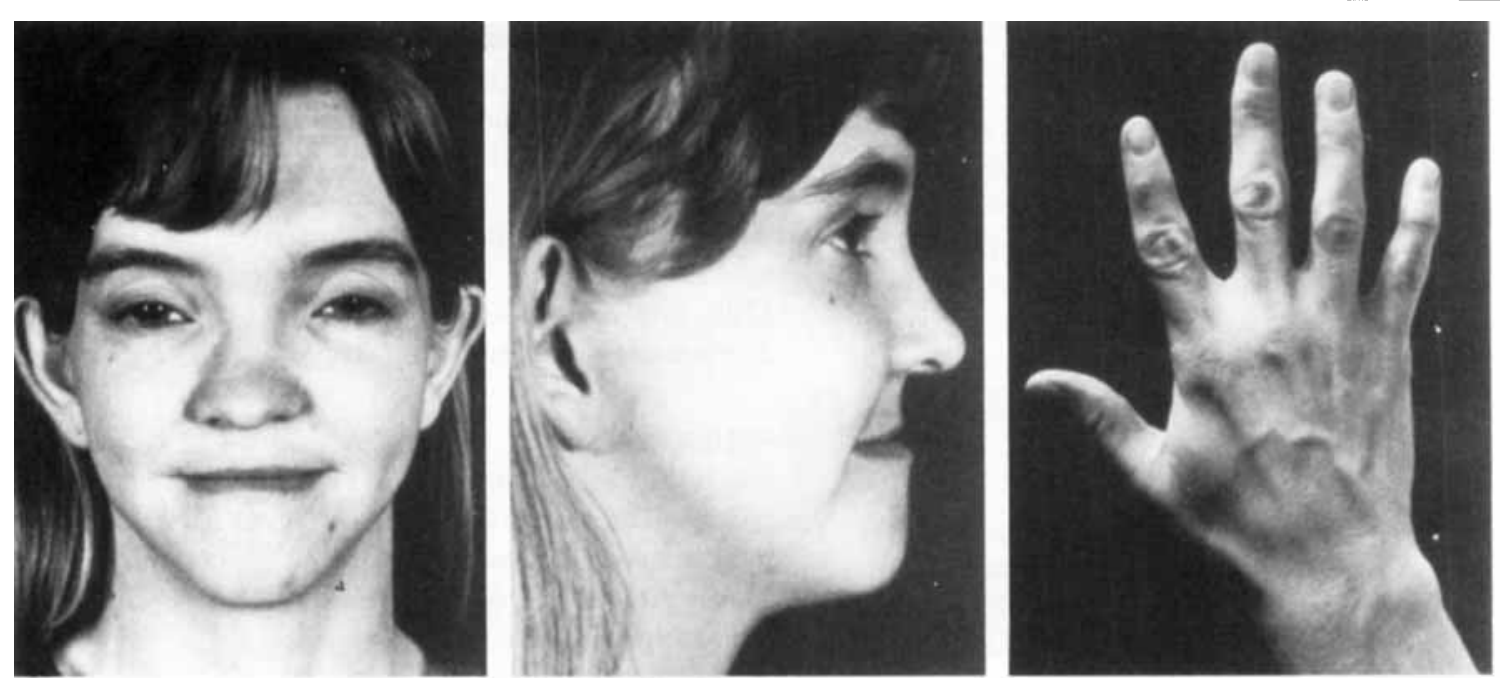

A

B
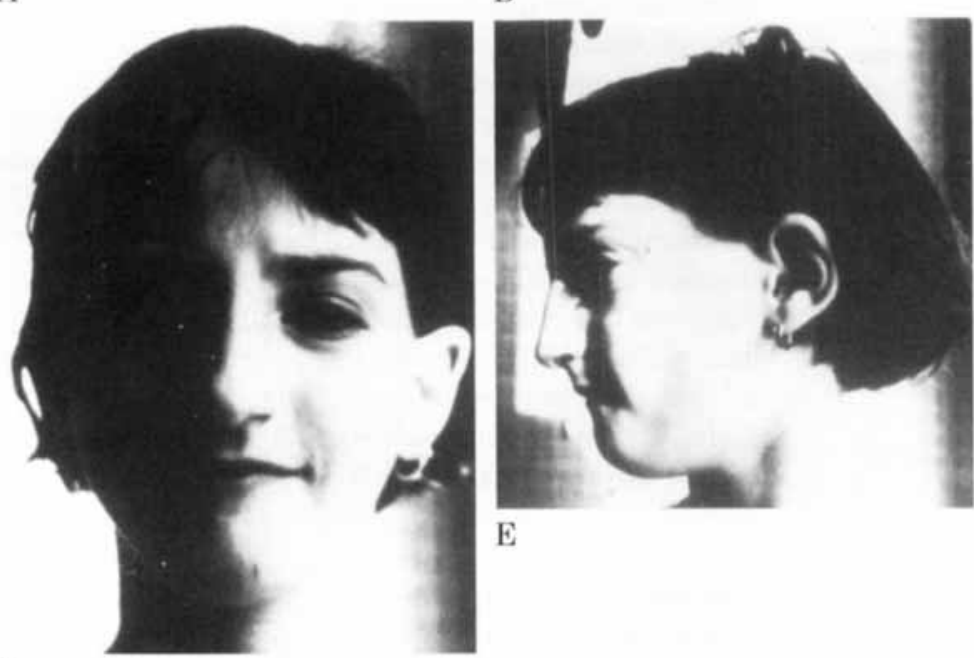

C

E

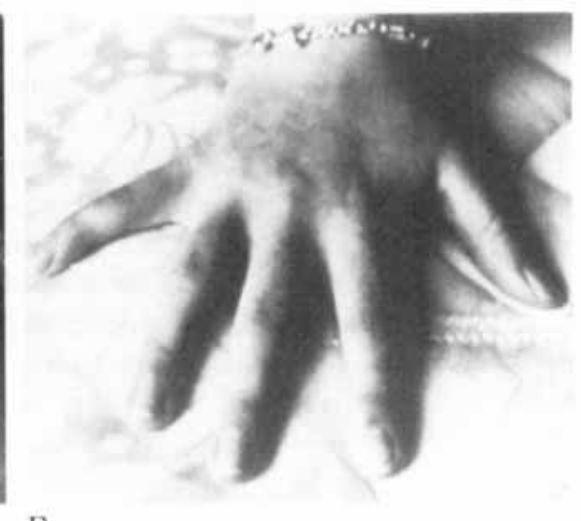

F

D
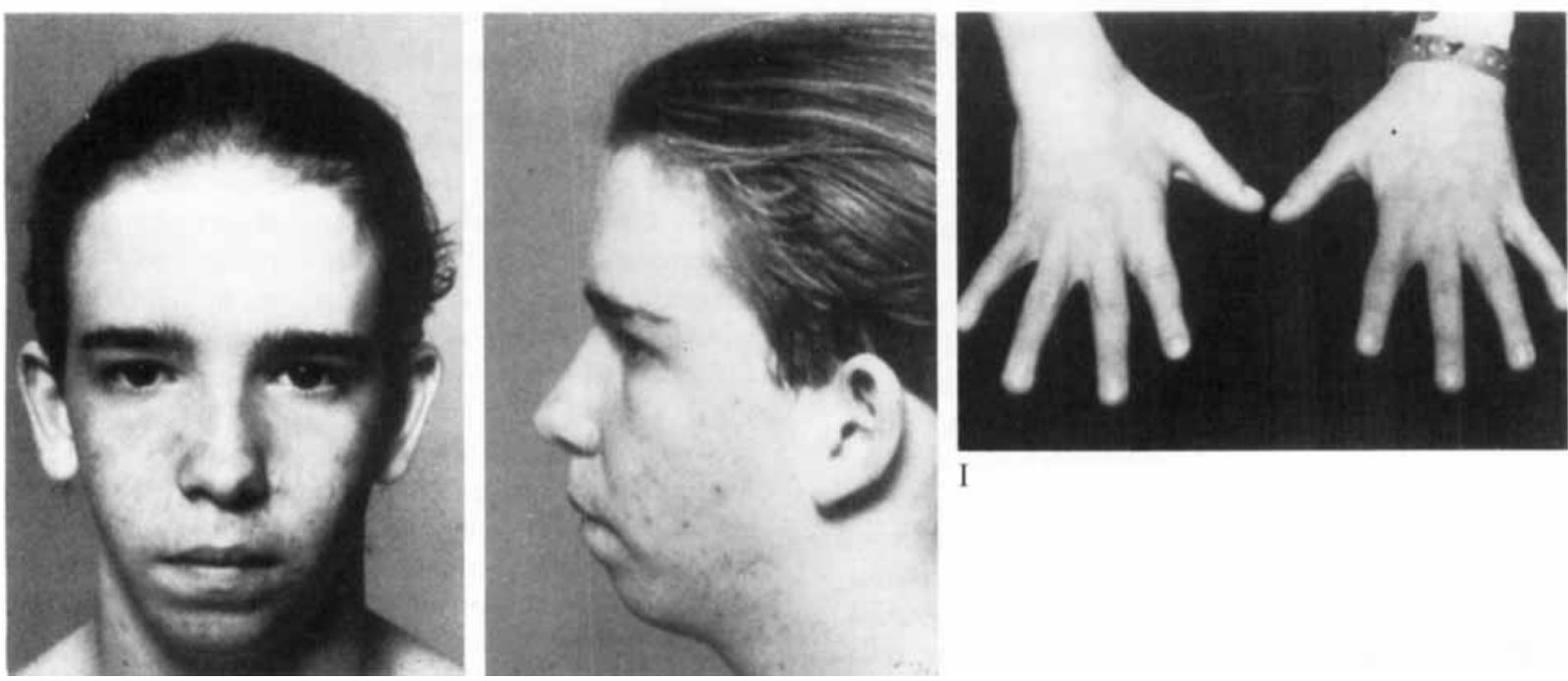

I

G

$\mathrm{H}$

Fig. Left row shows front views of Patienis 11,2 , and 5, respectively. Note the common traits, especially broad nose and low-set ears. Center row shows side views of the same patients, showing the recurrent small mandible in these patients. Right row shows the main skeletal dysmorphisms in the hands of these same patients. Note the abnormally short index finger of Patient 5 (I). 
Mild clinodactyly of the fifth fingers was found. Neurologic findings were normal.

PATIENT 10 (FAMILY 3, III-2). A 64-year-old man, the maternal grandfather of Patient 8, was found to have LQT syndrome $\left(\mathrm{QT}_{c}=0.6 \mathrm{msec}\right)$. He had no cardiac symptoms or limb weakness. Mild clinodactyly of the fifth fingers was found, with normal neurologic examination.

PATIENT 11. A 27-year-old woman was first evaluated at age 4 for episodic weakness associated with cramps and lasting 3 to 24 hours. Evaluation at age 8 showed normal to high serum potassium levels during attacks $(4.7 \mathrm{mEq} / \mathrm{L})$. A muscle biopsy was normal as were her serum creatine kinase (CK) levels. Hypokalemic challenge produced ventricular ectopy but no weakness, and provocative $\mathrm{K}^{+}$challenge to 7 $\mathrm{mEq} / \mathrm{L}$ abolished the ventricular arrhythmias but did not result in muscle weakness. At age 10 she had a nonfatal cardiac arrest, and a diagnosis of LQT syndrome with torsade de pointes was made $\left(\mathrm{QT}_{c}=0.56 \mathrm{msec}\right)$. Quinidine was started because of recurrent episodes of syncope, but it prolonged her QT interval further. Now, almost a year off quinidine, the patient has no further cardiac symptoms. Her physical examination revealed a slender woman with high-arched palate, hypertelorism, bilateral ptosis, micrognathia, broad forehead, as well as hyperlordosis and scoliosis (Fig A-C). Neurologic examination showed shoulder girdle atrophy with bilateral scapular winging associated with a 4- MRC grade proximal weakness in a "hip-girdle"-type distribution. Foot dorsiflexion was in the 4 - range. Tendon reflexes were absent. She experiences occasional palpitations and has had one near syncopal episode in the last 3 years. A recent Holter monitor revealed frequent premature ventricular contractions, occasionally in groups, although she had no symptoms during the study. She continues to have two or three episodes of weakness per month. The patient was adopted, so a clear family history could not be obtained. However, she was told that her mother had similar distinctive features and a maternal grandmother died of cardiac arrest at age 45 .

\section{Genetic Analysis}

ANDERSEN'S PEDIGREES. Three families were available to test the hypothesis that AS might be allelic with LQT syndrome. The kindreds were of insufficient size to demonstrate linkage with significant lod scores. However, given informative haplotypes, absence of linkage to a given locus can be demonstrated.

DNA ISOLATION AND MARKER ANALYSIS. High-molecular-weight genomic DNA was isolated from whole blood lisate with a phenol/chloroform extraction followed by isopropanol precipitation. Genetic evaluation was undertaken in kindreds 1784, 3387, and 3442, using markers that are tightly linked to LQT loci. The markers genotyped in these families are shown in Table 2. End-labeled primers were prepared as follows: 25 pmol of primer, $50 \mathrm{mM}$ Tris- $\mathrm{HCl}, 10$ $\mathrm{mM} \mathrm{MgCl} 2,5.0$ dithiothreitol, $8.4 \mathrm{U}$ of $\mathrm{T}_{4}$ polynucleotide kinase, and $6.0 \mu \mathrm{l}$ of $\left[\gamma-{ }^{32} \mathrm{P}\right] \mathrm{ATP}(5 \mathrm{~mol} / \mathrm{ml}$, in a total volume of $10 \mu \mathrm{l})$. This mixture was incubated at $37^{\circ} \mathrm{C}$ for 1 hour and was then heated to $94^{\circ} \mathrm{C}$ for 3 minutes to inactivate the $\mathrm{T}_{4}$ polynucleotide kinase.

The polymerase chain reaction (PCR) was used to amplify total genomic DNA, using primers flanking polymorphic regions. The reaction mixture contained $50 \mathrm{ng}$ of genomic DNA, 10 pmol of each primer, 1 pmol of the end-labeled primer, $2.5 \mathrm{nmol}$ of each deoxynucleoside triphosphate, 10 $\mathrm{mM}$ Tris- $\mathrm{HCl}\left(\mathrm{pH} \mathrm{8.4),50} \mathrm{mM} \mathrm{KCl,} 1.5 \mathrm{MgCl}_{2} 1.0 \mathrm{Taq}\right.$ DNA polymerase (Promega) in a volume of $25 \mu \mathrm{l}$. PCR was performed under the following conditions: (1) one cycle at $94^{\circ} \mathrm{C}$ for 3 minutes, (2) 30 cycles, each at $72^{\circ} \mathrm{C}$ for $45 \mathrm{sec}-$ onds, and (3) cooling to $4^{\circ} \mathrm{C}$. After PCR, $10 \mu \mathrm{l}$ of stop dye (98\% formamide, $0.05 \%$ bromphenol blue, $0.05 \%$ xylene cyanol, and $20 \mathrm{mM}$ EDTA) was added. Four microliters of each sample was then loaded on a $6 \%$ acrylamide gel that contained $5.6 \mathrm{M}$ urea, $32 \%$ formamide, $90 \mathrm{mM}$ Tris-borate, $\mathrm{pH} 7.5$, and 2 mM EDTA. Preelectrophoresis of gels was at a constant power $(80 \mathrm{~W} / \mathrm{gel})$ with $90 \mathrm{mM}$ Tris-borate $(\mathrm{pH}$ 7.5) and $2 \mathrm{mM}$ EDTA running buffer. Gels were placed on filter paper and exposed to x-ray film overnight at $-20^{\circ} \mathrm{C}$. Autoradiograms were analyzed for genotypes of the polymorphic alleles. The results of the DNA analysis on the recombinants to LQT loci are summarized in Table 2.

\section{Discussion}

In our initial study of AS, we defined a clinical triad to distinguish AS from other forms of periodic paralysis. The present study confirmed the validity of the triad, emphasizing intrafamilial phenotypic variability and establishing LQT as the most consistent cardiac manifestation. However, contrary to our initial report, the associated periodic paralysis can be hyper-, hypo-, or normokalemic [23].

In our initial report, 3 of 4 patients were normokalemic and 1 of 4 was hyperkalemic during spontaneous attacks. In all, attacks were induced by oral potassium challenge. They were therefore described as having potassium-sensitive periodic paralysis, implying a

Table 2. Recombinants to LQT Loci

\begin{tabular}{llll}
\hline & \multicolumn{3}{c}{ Kindred } \\
\cline { 3 - 4 } & 1784 & 3387 & 3442 \\
\hline LQT1 (KVLQT1) & & & \\
TH & $\mathrm{N}$ & $\#$ & $\#$ \\
D11S1318 & $\#$ & $\#$ & 0 \\
LQT2 (HERG) & & & \\
D7S505 & $\#$ & $\#$ & 0 \\
D7S483 & 0 & 0 & $\#$ \\
D7S636 & 0 & $\#$ & $\#$ \\
LQT3 (SCN5A) & & & \\
D351100 & $\#$ & $\#$ & \\
D3S1298 & & & \\
LQT4 (unk gene) & & 0 & \\
D4S193 & 0 & &
\end{tabular}

LQT = long QT; $(\#)=$ marker was uninformative in these families; $0=$ obligate recombinant; $N=$ previously reported nonobligate recombinant. 
pathogenic similarity with hyperkalemic periodic paralysis [13]. However, of the 5 index cases presented here, 2 were unequivocally hypokalemic during spontaneous attacks of weakness, and the remaining 3 were normoto mildly hyperkalemic. Potassium challenge was not performed in most patients because of the danger of worsening the cardiac arrhythmias. Potassium levels during spontaneous attacks were determined in each case. Although in most classical forms of periodic paralysis, changes in serum potassium are consistently unidirectional during attacks, "normokalemic" or biphasic attacks, occurring with either hypo- or hyperkalemic challenges have been reported in families with otherwise typical hyperkalemic periodic paralysis [24-26]. We therefore conclude that, like other periodic paralysis, serum potassium shifts are inconsistent in the periodic paralysis of AS and that the traditional classification of hyper- or hypokalemic periodic paralysis cannot be applied. That shifts in serum potassium levels in Andersen's periodic paralysis are unconventional is underscored by the absence of mutations in either the sodium channel or the calcium channel genes responsible for typical hyperkalemic [14-16] and hypokalemic [19] periodic paralysis.

In retrospect, evaluation of changes in serum potassium in AS should be done only during spontaneous attacks of weakness. Provocative challenges, especially hypokalemic challenges, should not be undertaken in AS patients because hypokalemia may exacebate preexisting QT prolongation and potentially cause lifethreatening ventricular arrhythmias.

The constancy and distinctness of the physical fea- tures in the cases presented demonstrate that they represent an integral part of this syndrome. Although these features were clearly present in all our index cases (see Fig), there was substantial variability in the clinical expression within each family (Tables 3 and 4).

The cardiac disorder of AS varies from asymptomatic LQT to potentially fatal ventricular tachyarrhythmias. The QT interval was prolonged in 12 of 15 of reported cases [13], some antedating the onset of episodic weakness. In 2 kindreds described here, grandparents of the index cases had isolated asymptomatic LQT. This observation suggests a clinical overlap between typical LQT and AS. It is noteworthy that LQT patients may show syndactyly without periodic paralysis $[27,28]$. Although the phenotypic variability in our kindreds might suggest anticipation, ascertainment bias or random variability in disease expression cannot be excluded, given the small number of cases.

Linkage analysis had previously excluded linkage of AS to the HyperKPP locus on chromosome 17 as well as to the LQT1 locus on chromosome 11 [13]. Linkage studies in the present kindreds confirm these observations. In addition, mutation analysis excluded common HypoKPP mutations in the dihydropyridine receptor gene [19].

Because cardiac and skeletal muscle contain different isoforms of the major ion channel proteins, the coexistence of abnormalities of cardiac and skeletal muscle membrane excitability in AS suggests that the pathogenic mechanism must alter the function of more than one specific channel. This could be achieved by a defective regulatory protein common to both tissues [29].

Table 3. Summary of Clinical Data

\begin{tabular}{|c|c|c|c|c|c|c|c|c|c|c|c|c|c|c|c|}
\hline & \multicolumn{15}{|c|}{ Patient } \\
\hline & 1 & 2 & 3 & 4 & 5 & 6 & 7 & 8 & 9 & 10 & 11 & $12^{\mathrm{a}}$ & $13^{a}$ & $14^{a}$ & $15^{2}$ \\
\hline $\begin{array}{l}\text { Onset of muscle } \\
\text { symptoms (yr) }\end{array}$ & 10 & - & 18 & - & 14 & 4 & - & 2 & - & - & 4 & 10 & 15 & 13 & 18 \\
\hline $\begin{array}{l}\text { Onset of cardiac } \\
\text { symptoms (yr) }\end{array}$ & 6 & - & 13 & - & 7 & - & - & - & - & - & 10 & - & - & - & - \\
\hline $\begin{array}{l}\text { Spont }\left[\mathrm{K}^{+}\right] \\
(\mathrm{mEq} / \mathrm{L})\end{array}$ & 2.5 & $\mathrm{ND}$ & $\mathrm{N} D$ & ND & 2.7 & 4.3 & - & 4.1 & ND & ND & 4.7 & ND & ND & ND & 5.2 \\
\hline Interattack weakness & + & - & - & - & + & + & - & + & - & - & + & + & + & + & + \\
\hline Myotonia & - & - & - & - & - & - & ND & - & - & - & - & - & - & - & - \\
\hline $\mathrm{CK}(\mathrm{IU})$ & $1-2 x$ & $1-2 \times$ & $N$ & $N$ & $N$ & $\mathrm{~N}$ & $\mathrm{~N}$ & $1-2 x$ & $\mathrm{~N}$ & $\mathrm{~N}$ & $\mathrm{~N}$ & $1-5 x$ & $1-2 \times$ & $\mathrm{N}$ & $1-2 x$ \\
\hline Muscle biopsy & TA & ND & TA & ND & $\mathrm{N}$ & TA & ND & TA & ND & ND & $\mathrm{TA}$ & $\mathrm{TA}$ & ND & TA & TA \\
\hline $\mathrm{QT}_{\mathrm{c}}(\mathrm{msec})$ & 0.47 & 0.48 & 0.47 & 0.48 & 0.48 & 0.47 & 0.48 & 0.46 & 0.52 & 0.60 & 0.47 & 0.48 & 0.43 & 0.46 & 0.56 \\
\hline BVT & + & + & + & - & + & + & - & + & + & - & + & + & + & + & - \\
\hline Cardiac arrest & + & - & - & - & - & - & - & - & - & - & - & - & - & - & - \\
\hline Dysmorphisms & + & + & + & + & + & + & - & + & + & + & + & + & + & + & + \\
\hline Heredity & $\mathrm{AD}$ & $\mathrm{AD}$ & $\mathrm{AD}$ & $\mathrm{AD}$ & S? & $\mathrm{AD}$ & $\mathrm{AD}$ & $\mathrm{AD}$ & $\mathrm{AD}$ & AD & $\mathrm{AD} ?$ & $\mathrm{AD}$ & AD & $S ?$ & $S ?$ \\
\hline
\end{tabular}

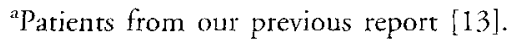

Spont $\left[\mathrm{K}^{+}\right]=$serum potassium levels (in $\mathrm{mEq} / \mathrm{L}$ ) during a spontaneous attack of weakness; $\mathrm{CK}=$ creatine kinase; $(+)=$ present; $(-$ ) $=$ absent; $\mathrm{N}=$ normal; $\mathrm{ND}=$ not done; $\mathrm{TA}=$ tubular aggregates; $\mathrm{BVT}=$ bidirectional ventricular tachycardia; $\mathrm{AD}=$ autosomal dominant; $\mathrm{S}=$ sporadic. 
Table 4. Main Dysmorphic Features in AS

Facial and Skeletal

Abnormalities

No. of Patients

\begin{tabular}{ll}
\hline Face & \\
Eyes: hypertelorism & 5 and $3^{\mathrm{a}}$ \\
Ears: low set & 7 and $2^{\mathrm{a}}$ \\
Nose: broad & 2 and $2^{\mathrm{a}}$ \\
Mandible: small & 7 and $3^{\mathrm{a}}$ \\
Hands & 7 and $4^{\mathrm{a}}$ \\
$\quad$ Clinodactyly & 1 \\
Abnormal digit length & 2 \\
Abnormal palm length & 3 \\
Feet & \\
Syndactyly & 2 \\
Palate & \\
High arched & 1 \\
Skull & \\
Scaphoencephalic & 3 and $1^{\mathrm{a}}$ \\
Vertebral column & \\
Scoliosis
\end{tabular}

${ }^{\text {a }}$ Patients from our previous report [13].

AS $=$ Andersen's syndrome.

In contrast, the genetic lesion could involve more than one gene. Multiple channel abnormalities have been documented by patch-clamp techniques in SchwartzJampel syndrome, a disorder similar to AS in combining abnormal skeletal muscle membrane excitability with distinctive skeletal features $[30,31]$. The gene le$\operatorname{sion}(s)$ responsible for AS must also explain the characteristic physical findings. This complex phenotype also suggests a genetic disorder of multiple genes. However, Holt-Oram syndrome, the prototypical hearthand disorder, is the result of a single gene mutation $[32,33]$.

Genetic heterogeneity in periodic paralysis with cardiac arrhythmia is likely. Before our 1994 report, other patients with periodic paralysis and cardiac arrhythmias had been described (see Table 1) [1, 4-12]. Only 2 were noted to have distinctive physical features $[4,10]$ and none had a prolonged QT, although it is unclear whether these features were specifically looked for. However, with the recent description of a case of periodic paralysis with cardiac arrhythmias associated with a sodium channel mutation [12], it appears possible that there exist syndromes of periodic paralysis with cardiac involvement distinct from AS, although the gene defect has still to be identified.

Our data indicate that AS is a unique autosomal dominant disorder with distinctive clinical features and that it is genetically distinct from the common forms of periodic paralysis and LQT syndromes. The full clinical triad includes (1) hypo-, normo-, or hyperkalemic periodic paralysis, (2) prolonged QT interval in $80 \%$ of cases and ventricular arrhythmias, and (3) distinctive physical features. However, partial manifesta- tions of the syndrome are common in family members of patients with the full AS triad, often with a prolonged QT interval as the minimal manifestation. Recognition of this potentially life-threatening disorder is essential in the diagnostic workup of all patients with suspected periodic paralysis. $\mathrm{QT}_{\mathrm{c}}$ intervals should be measured and, if prolonged, diagnostic hypokalemic and hyperkalemic challenges should be avoided, in favor of graded exercise protocols designed to precipitate attacks of paralysis. In a similar manner, AS should be considered in the differential diagnosis of LQT syndromes, especially in the presence of distinctive physical features.

This study was supported by NIH grants M01-RR004 and R01NS22099, the Wayne C. Garrell Jr Molecular Biology Laboratory, NIH grant NS32711, the Eccles Program in Human Molecular Biology and Genetics, and the H.A. Benning Endowment (to L.P.) and the MDA (L.P.), and Public Health Service research grant M01-RR00064 from the National Center for Research Resources.

We are grateful to Dr P. J. Schwartz (Division of Cardiology, University of Pavia, Pavia, Italy) for referring Family 1 to us and Dr A. Moss (Division of Cardiology, University of Rochester, Rochester, NY) for advice on the care of the patients. We thank Dr L. P. Rowland for helpful suggestions and constructive criticism.

\section{References}

1. Klein R, Ganelin R, Marks JF, et al. Periodic paralysis with cardiac arrhythmia. I Pediatr 1963;62:371-385

2. Lehmann-Horn F, Engel A, Ricker K, Rudel R. The periodic paralyses and paramyotonia congenita. In: Engel AG, FranziniArmstrong C, eds. Myology. 2nd ed. New York: McGraw-Hill, 1994:1303-1334

3. Griggs RC. Periodic paralysis. Semin Neurol 1983;3:285-293

4. Lisak RP, LeBeau J, Tucker SH, Rowland LP. Hyperkalemic periodic paralysis with cardiac arrhythmia. Neurology 1970;20: 386 (Abstract)

5. Andersen ED, Krasilnikoff PA, Overvad H. Intermittent muscular weakness, extrasystoles, and multiple developmental abnormalities: a new syndrome? Acra Pediatr Scand 1971;60: $559-564$

6. Levitt LP, Rose LI, Dawson D. Hypokalemic periodic paralysis with arrhythmia. N Engl J Med 1972;286:253-254

7. Stubbs WA. Bidirectional ventricular tachycardia in familial hypokalemic periodic paralysis. Proc R Soc Med [Biol] 1976;69: 223-224

8. Kramer LD, Cole JP, Messenger JC, Ellesrad MH. Cardiac dysfunction in a patient with familial hypokalemic periodic paralysis. Chest 1979;75:189-192

9. Yoshimura T, Kaneuji M, Okuno ' $T$, et al. Periodic paralysis with cardiac arrhythmia. Eur J Pediatr 1983;140:338-343

10. Gould RJ, Steeg CN, Eastwood AB, et al. Potentially fatal cardiac dysrhythmia and hyperkalemic periodic paralysis. Neurology 1985;35:1208-1212

11. Fukuda K, Ogawa S, Yokozuka $\mathrm{H}$, et al. Long-standing bidirectional tachycardia in a patient with hypokalemic periodic paralysis. J Electrocardiol 1988;21:71-76

12. Baquero JL, Ayala RA, Wang J, et al. Hyperkalemic periodic paralysis with cardiac dysrhythmia: a novel sodium channel mutarion? Ann Neurol 1995;37:408-411

13. Tawil R, Ptacek LJ, Pavlakis SG, et al. Andersen's syndrome: 
potassium sensitive periodic paralysis, ventricular ectopy, and dysmorphic features. Ann Neurol 1994;35:326-330

14. Ptacek LJ, Tyler F, Trimmer IS, et al. Analysis of a large hyperkalemic periodic paralysis pedigree supports tight linkage to a sodium channel locus. Am J Hum Genet 1991;49:278-282

15. Ptacek LJ, George AL Jr, Griggs RC, et al. Identification of a mutation in the gene causing hyperkalemic periodic paralysis. Cell 1991;67:1021-1027

16. Fontaine B, Khurana TS, Hoffman EP, et al. Hyperkalemic periodic paralysis and the adult sodium channel $\alpha$-subunit gene. Science 1990;250:1000-1002

17. Keating $M$, Atkinson D, Dunn $C$, et al. Linkage of a cardiac arrhythmia, the long QT syndrome, and the Harvey ras-1 gene. Science 1991;252:704-706

18. Wang Q, Curran ME, Splawski I, er al. Positional cloning of a novel potassium channel gene: KVLQT1 mutations cause cardiac arrhythmias. Nat Genet 1996;12:17-23

19. Ptacek LJ, 'Tawil R, Griggs RC, et al. Dihydropyridine receptor mutarions cause hypokalemic periodic paralysis. Cell 1994;77: $863-868$

20. McManis PG, Lambert EH, Daube JR. The exercise test in periodic paralysis. Muscle Nerve 1986;9:704-710

21. Schwartz PJ, Moss AJ, Vincent GM, Crampton RS. Diagnostic criteria for the long QT syndrome: an update. Circulation 1993;88:782-784

22. Martin AB, Perry JC, Robinson JL, et al. Calcularion of QTC duration and variability in the presence of sinus arrhythmia. Am J Cardiol 1995;75:950-952

23. Rowland I.P. Andersen's syndrome? Or Klein-Lisak-Andersen syndrome? Ann Neurol 1994;35:252-253 (Letter)
24. Rowland LP, Lisak RP. Periodic paralysis: $\mathrm{K}$ levels during arrhythmia. N Engl J Med 1972;287:50 (Letter)

25. Layzer RB, Lovelace RE, Rowland LP. Hyperkalemic periodic paralysis. Arch Neurol 1967;16:455-472

26. Lewis ED, Griggs RC, Moxley RT. Regulation of plasma potassium in hyperkalemic periodic paralysis. Neurology 1979;29: $1131-1137$

27. Marks ML, Trippel DL, Keating M. Long QT syndrome associated with syndactyly identified in females. Am J Cardiol 1995;76:744-745

28. Marks ML, Whisler SL, Clericuzio C, Keating M. A new form of long QT syndrome associated with syndactyly. J Am Coll Cardiol 1995;25:59-64

29. Sperelakis N. Regulation of calcium slow channels of heart by cyclic nucleorides and effects of ischemia. Adv Pharmacol 1994; $31: 1-24$

30. Rudel R, Ruppersberg JP, Spittelmeister W. Abnormalities of the fast sodium current in myotonic dystrophy, recessive generalized myotonia, and adynamia episodica. Muscle Nerve 1989;12:281-287

31. Lehmann-Horn F, Iaizzo PA, Franke C, et al. Schwartz-Jampel syndrome: II. $\mathrm{Na}+$ channel defect causes myotonia. Muscle Nerve 1990;13:528-535

32. Basson CT, Cowley GS, Solomon SD, et al. The clinical and genetic spectrum of the Holt-Oram syndrome (heart-hand syndrome). N Engl J Med 1994;330:885-891

33. Basson CT, Solomon SD, Weissman B, et al. Genetic heterogeneity of heart-hand syndromes. Circulation 1995;91:13261329 